\title{
EFFECT OF DEHYDRATION, PRODUCED BY MERCUPURIN, ON THE PLASMA VOLUME OF' NORMAL PERSONS
}

\author{
Richard H. Lyons, M.D., Noyes L. Avery, M.D., AND \\ Samuel D. Jacobson, M.I)." \\ ANn ARbor, Mich.
}

$\coprod^{\mathrm{T}}$ HAS been assumed ${ }^{1,2}$ that the plasma rolume remains relatively constant with dehydration because it is protected by the much laroer extracellular fluid volume. Using improved techniques for measurement of the plasma volume, however, it has been found that considerable derreases in the plasma volume may be associated with dehydration induced in animals by removal of intestinal fluid ${ }^{3}$ or the intraperitoncal injection of glueose, ${ }^{4}$ and in man by diabetic acidosis and the admin. istration of ammonium chloride. ${ }^{6}$

There is considerable variation of opinion concerning the mode of action and the cffcetiveness of mercurial diureties in different diseases because of the variability in the diuretie response from patient to patient as well as in a single patient. When edema is mesent, it is difficult to evaluate the role played by diuretic drugs because of the spontaneous variations in the pathologic process. In general, it may be said that the diuretic response in patients with heart. failure is ronghly proportional to the amount of edema. ${ }^{\text {? }}$

There is little information ${ }^{8}$ concerning the action of mercurial diureties on normal subjects, and, consequently, there is no standard upon which diuresis may be evaluated. Occasionally, these diuretics are administered to patients who no longer exhibit clinical evidence of edema, and, when diuresis results, it may he interpreted as evidenee of "subclinical edema."

These observations were made on normal subjets in an effort to estahlish a base line by which the diuretic effect of a single dose of one organic mereurial compound might be evaluated. and to assay the effect of this twpe of dehydration upon the plasma volume.

\section{METHODS}

Ten patients in good health, who were free from cardiovascular or renal disease and had never had edema, were selected as normal subjects for study. Each subject had been on the routine hospital diet, with fluid and salt ad lib., for several days before the ohservations, and was presumably in a "normal state of hydration."

On the day the observations were started, the subject was weighed in the rested, postabsorptive state on a beam balanee which was aceurate to

Frem the Devartment of Internal Medicine, University of Michigan, and the William J. Seymour Division of the Floise Hospital, Eloise. Michigan.

Supported by grants from the Board of Directors of the Horace H. Rackham School for Graduate Study, and the Upjohn Company, Kalamazoo, Michigan.

Received for publication July $31,1943$.

* Ipjolin fellow in research. 
2 grams. After the weighing, he was placed on a table, and blood samples were taken for determination of the plasma volume, ${ }^{\theta}$ hematocrit, ${ }^{10}$ and serum proteins. ${ }^{11}$ After forty-five minutes on the table, estimations of the arterial and venous blood pressures ${ }^{12}$ were made. and, at the conclusion of the observations, 2 c.c. of mercupurin were injected, intravenously. During the day, the patient was allowed fluids ad lib. and consumed all the food on his trays. The following morning the subject was again weighed, and the observations were repeated while he was in the rested, postabsorptive state.

If the subject consumes his usual diet, changes in weight from one day to the next will reflect closely changes in the water content of the body. It can, therefore, be assumed that the weight lost twenty-four hours after an injection of mercupurin closely approximates the diuresis produced. The error of such an assumption is of little significance in dealing with the large changes in weight which were observed.

Control determinations of the plasma volume and hematocrit were repeated twenty-four times on successive mornings on twenty-two normal subjects. There was a mean difference between the determinations of plasma volume of $+27.5 \pm 19.1$ c.c., or $+0.95 \pm 0.64$ per cent of the initial volume, and a mean percentage change in the hematocrit of $-0.75+0.52$. In thirteen repeated determinations of the total serum protein, there was a mean percentage change of $-0.60 \pm 1$ per cent.

\section{RESULTS}

All subjects experienced a diuresis, and in every case there was a fall in the plasma volume, associated with an increase in the hematocrit reading and serum protein concentration. The changes in plasma volume, serum protein concentration, hematocrit, venous pressure, and body weight are presented in Table $I$. The percentage change expresses the variations in plasma volume for the group more accurately than the actual change, for the plasma volume will vary considerably with the size of the subject.

Although all of the subjects had a diuresis, there was considerable variation in the degree of response. The average weight loss was 1.73 $0.3 \mathrm{~kg}$., or $2.64 \pm 0.5$ per cent of the body weight. Two subjects, No. 2 and No. 10, had a $3.5 \mathrm{~kg}$. weight loss, while two others lost only 0.5 and $0.7 \mathrm{~kg}$., respectively. The larger subjects underwent a greater ehange in weight than the smaller ones.

The fall in plasma volume was roughly proportional to the extent of diuresis. The average decrease in the plasma volume was $544 \pm 87.7$ c.c., or $-15.7 \pm 2.4$ per cent of the initial plasma volume. In two cases, No. 7 and No. 9, the change in the plasma volume was small, and in each instance the diuresis was considerably below the arerage for the group. The percentage increase in serum protein concentration and hematocrit was considerably less than the decrease in plasma volume. The average change in serum proteins was $+0.74 \pm 0.14 \mathrm{Gm}$., or $+11.5 \pm 2.6$ per cent. There was a mean increase in the packed cells of the hematocrit of

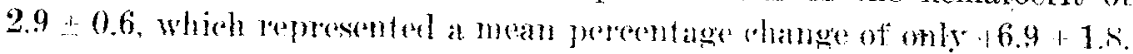




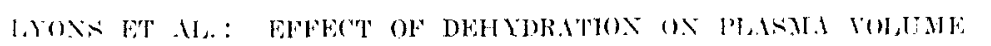

$24 !$

TABLE: 1

Changes Twenty-Four Hours After the Administration of 2 c.c. OF Mercupurix TO TEN NORMaL SUbJECTS

\begin{tabular}{|c|c|c|c|c|c|c|c|c|c|c|c|c|c|}
\hline 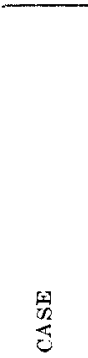 & 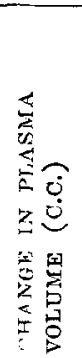 & 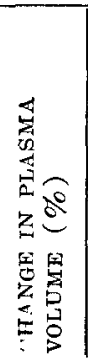 & 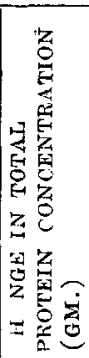 & 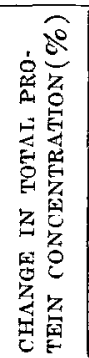 & 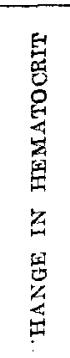 & 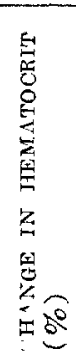 & 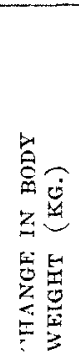 & 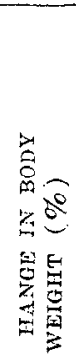 & 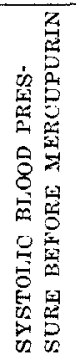 & 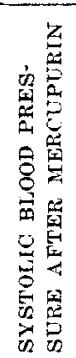 & 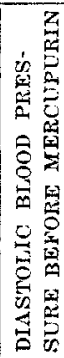 & 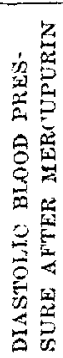 & 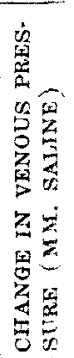 \\
\hline 1 & -580 & -20.2 & +1.56 & +26.5 & & 18 & 46 & -18 & 120 & 108 & 84 & 86 & -25 \\
\hline 2 & & & & & & & & & & & & & \\
\hline 3 & & 9 & & +11 & & & & e. & & 9 & & 12 & 17 \\
\hline 4 & & 0 & & & & & & & & 11 & & & $3 x$ \\
\hline 5 & & & & & & & & & & & & & \\
\hline 6 & & -19.5 & & & & & & & & 10 & 74 & & 18 \\
\hline 7 & & -1 & & & & & & & & & & & \\
\hline & & -1 & +0.30 & +3.5 & & & & -4 & 100 & $I^{\prime} ; 0$ & & & 45 \\
\hline 9 & & & -- & -- & & & & & 90 & 42 & 70 & o & 5 \\
\hline 10 & -760 & -21.2 & & -- & +6.0 & +16.7 & $-3 . \tilde{5}$ & -5.6 & 110 & 105 & 70 & 90 & 62 \\
\hline & & $-15 . i$ & +0.7 & +11.5 & & & & 2.64 & $11 \%$ & 104.8 & 77.4 & & 25. \\
\hline & & & & 6.9 & & & & & & & & & \\
\hline & \pm 87.7 & \pm 2.4 & \pm 0.14 & \pm 2.6 & \pm 0.6 & -1.0 & \pm 0. & $\pm 0,5$ & \pm 0.2 & $\begin{array}{l}+2.6 \\
\end{array}$ & \pm 2.1 & & \pm 5. \\
\hline
\end{tabular}

Accompanying the diuresis there was a fiall in the renous pressure in every case; in some instances this was quits striking, whereas in of hers it was of little significance. There was an average decrease of $25.2: 5.3$ mm. of saline from the control determination. The control venous pressure measurements were all normal, ranging from 70 to $136 \mathrm{~mm}$. of water. There was no significant relationship between the control level of venous pressure and the degree of change. The changes that were most pronounced occurred in Cases 4,8 , and 10 , in which the control venous pressures were 78,120 , and $100 \mathrm{~mm}$. saline, respectively. In general, the fall in renous pressure roughly paralleled the decrease in plasma volume and body weight. There was also a significant decrease. in the pulse pressure, with a rise in the diastolic pressure and a fall in systolic pressure.

The majority of the subjects observed no change in their state of wellbeing except some increase in lassitude. A few noted a sensation of weakness and tiredness in the supine position, with dizziness and lightheadedness on standing. This was particularly evident in Cases 1. 5, and 10 .

\section{DISCUSSION}

'There are many contlicting reports in the literature concerning the changes in the plasma volume after giving mercurial diureties. This conflict is probably the result of deductions drawn from slight variations in the constituents of the plasma, from differences in the time the observations were made, and, possibly, from different types of experimental material. 
Many investigators have used alterations in the concentration of serum proteins as an index of change in plasma volume. Some ${ }^{13}$ reported decreases in the plasma protein concentration shortly after the injection of a mercurial diuretic, followed later, in some instances, by a rise in the plasma protein. Others ${ }^{14}$ observed no decrease in the plasma protein, but a consistent increase in its concentration during and after the period of diuresis. Studies based on techniques that measure the plasma volume directly also are in disagreement. Feher ${ }^{15}$ found that there was an elevation of the plasma volume either at the height of the diuresis or after diuresis. Brown and Rowntree ${ }^{16 \mathrm{~A}}$ and Swigert and Fitz $^{16 \mathrm{~B}}$ found changes in the blood volume in either direction. Goldhammer, et al., ${ }^{17 \mathrm{~A}}$ Evans and Gibson, ${ }^{1 \% \mathrm{~B}}$ Calvin and Decherd, ${ }^{17 \mathrm{C}}$ and Herrmann and Decherd ${ }^{17 \mathrm{D}}$ reported that consistent decreases in the plasma volume were present with the onset of diuresis and at the completion of diuresis.

The changes in protein concentration and plasma volume have been used to support theories concerning the artion of mereurial diuretics. The demonstration of a decrease in plasma protein concentration and an increase in plasma volume is used to support the theory that these drugs act on the tissues and mobilize tissue fluid. The observers who found increases in protein concentration and decreases in plasma volume consider that these changes are evidence of direct action of the mereurial diuretics on the kidney. This view receives strong support from the work of Goverts, ${ }^{18}$ Christian and Bartram, ${ }^{19}$ Herrmann, et al., ${ }^{20}$ and Blumgart et al., ${ }^{7,8}$ who have approached the problem in a different manner. If the action of mercurials is directly on the kidneys, presumably through diminished tubular absorption as the preponderance of more recent work would suggest, then the plasma volume should fall as tubular absorption is impaired, unless it is completely protected by the extracellular fluid. There would appear to be no reason to expect an increase in plasma volume under these circumstances unless protein were added to the blood stream, as suggested by Nonnenbruch. There is no evidence, however, that protein is added to the blood stream; it may actually be lost in certain instances. ${ }^{21,22}$

The results reported here cannot answer the question whether there are shifts in the plasma volume before or at the time of diuresis. The measurement of plasma volume twenty-four hours after the injection of mercupurin will reflect only the end result of the diuresis. As such, however, there appears to be no suggestion that hydremia has occurred. It is also evident that the plasma volume is not well supported by the extracellular fluid volume.

If the action of mercurial diuretics is directly on the kidney, it might be expected that the plasma volume of normal subjerts would suffer greater changes in proportion to the fluid lost than that of an edematous subject, which is presumably supported by a larger volume of extra- 
cellular fluid. This may, in part, explain the inconsistent results of Swigert and Fitz ${ }^{16 B}$ and others who studied edematous patients. It does not explain an increase in the plasma volume after diuresis, and this did not occur in the cases reported here.

Blumgart, et al., ${ }^{8}$ in a careful balance study of two normal subjects who were undergoing salyrgan diuresis, calculated that 90 per cent of the water lost under these circumstances comes from the extracellular fluid, and only 10 per cent from the tissues. The results in these ton subjects indicate that the decrease in plasma volume contributes greatly. to the weight lost. The loss of plasma rolume would account for $39.6 \pm 9.5$ per cent of the decrease in body weight. In Cases 4 and 6 . the decrease in plasma volume accounted for nearly all of the change in body weight. If these cases are eliminated, the change in rlasma volume in the remaining eight cases accounts for 26.3 . 3.8 per rent of the weight lost. This is in striking contrast to the effect of ammonium chloride diuresis in a similar group of normal subjects," in which the decrease" in plasma volume accounted for only $12.2 \div 1.2$ per cent of the wejoht lost.

It is interesting that the average diureses observed in this group of normal subjects after 2 e.c. of mereupurin, namely, 2.6 per cent of thr body weight, was less than that which occurred in a similar group on a low-salt diet and ammonium chloride $;^{6}$ the latter had an average diuresis of 4.4 per cent of the body weight after a three- or four-day period. Ordinarily, patients with edema do not have a greater diuresis with ammonium chloride than with mereupurin. This discrepancy in thesc normal subjects may be explained by the fact that, with ammonium chloride, water is lost from both fluid compartments in nearly equal amounts, ${ }^{23}$ whereas, with mercupurin, water is lost largely from the extracellular fluid compartment. Thus, in the absence of abnormal accumulations of extracellular fluid, ammonium chloride administration might be expected to produce a greater woight loss.

These results suggest that a normal subject may have a diuresis of 2 to 6 pounds, or 1 to 4 per cent of the body weight, in response to a 2 ce. injection of mercupurin. At times, after a patient has recovered from congestive heart failure, diureties are still used when there is no longer dinical evidence of edema. When a diumsis of six pounds ${ }^{\prime}$ less occurs in such eases, it should not necessarily be interpreted as nidence of abnormal accumulations of edema fluid, and should suggest that further diuresis may not be necessury. Such a diuresis should not be interpreted as evidence of "subclinical edema." Furthermore, the administration of mereurial diureties to such palients may produce severe dehydration and the elinical picture chatacterized by weakness. apathy, delirium, and, at times, unconsciousness, deseribed by Poll and Stern. ${ }^{24}$ 
The failure of the concentration of serum protein and the hematocrit readings to increase in proportion to the fall in plasma volume under these circumstances has been noted before. ${ }^{25}$ This again is evidence that shifts in these components fail to reflect quantitatively the change in plasma volume, although they may indicate that the plasma volume is undergoing changes, and the direction of the change.

The consistent fall in the venous pressure in these cases appears to be related to the decrease in plasma volume and body weight. Large changes in the plasma volume, with two exceptions, Cases 2 and 6 , were accompanied by pronounced changes in the venous pressure. Since the veins of the forearm are a series of collapsible tubes, the pressure in them is dependent upon the pressure of the surrounding tissues, ${ }^{25}$ the intrathoracic pressure, ${ }^{28}$ and the pressure in the right auricle. ${ }^{27}$ Ryder, Molle, and Ferris ${ }^{26}$ have indicated that the pressure in a peripheral vein in normal subjects is a function of tissue pressure causing collapse of that vein along its course to the heart, so that it is independent of the auricular pressure. Richards, et al., ${ }^{27}$ found a gradient of $39 \mathrm{~mm}$. of water between the antecubital venous pressure and the auricular pressure in nine normal subjects. The gradient tends to disappear as the pressure in the auricle rises in congestive heart failure. The pressure in the peripheral veins is not changed by decreases in the intrathoracic pressure below normal, but will be affected by increased intrathoracic pressure. ${ }^{28}$ Another factor, however, must be considered in evaluating the decrease in venous pressure. Warren and Stead ${ }^{29}$ found that, with pooling of blood in the lower extremities of six normal subjects, there was a fall in the antecubital venous pressure of $23 \mathrm{~mm}$., and, in the external jugular pressure, of $53 \mathrm{~mm}$. Under these circumstances, the decrease in the amount of blood returning to the auricle was the chief factor affecting the venous pressure, and it would appear that either the volume of blood flow or the auricular pressure, or both, had some effect on the peripheral venous pressure.

The fall in venous pressure after the injection of mercupurin may be explained by several factors. The loss of extracellular fluid in the tissues surrounding the antecubital vein may result in a decrease in tissue pressure. In these cases, the weight loss was relatively small, and it appears unlikely that this factor would be of great importance. The decrease in arterial pulse pressure and the symptoms of weakness and apathy at rest in bed and dizziness and faintness in the upright position experienced by some of these subjects suggest that there was a decrease in the blood flow. This might produce the fall in venous pressure as a result of the decreased filling of the vascular. bed in the region of the antecubital vein, thereby decreasing the tissue tone. The decrease in blood flow, if present, may be the result of a decrease in the auricular pressure associated with the lower plasma volume, which may be reflected by the fall in the antecubital venous pressure. The failure to demonstrate more consistent changes in the venous 


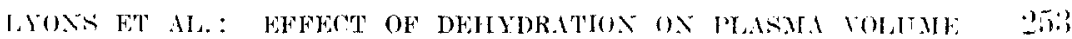

pressure under these circumstances may be the result of individual variation in the degree of local obstruction to the flow of blood in the antecubital vein, which thus masks changes in the auricular pressure.

The simptoms exhibited by some of these normal subjects are similar. in many respects to those noted by edematous subjects after extensive diuresis, ${ }^{24}$ and suggest that diminishing blood rolume may play an important role. The clinical picture of apathy, woakness, delirium, and unconsciousness after extensive diuresis and the symptoms associated with a diminished blood volume which were noted by the normal subjecls are analogous, in many ways, to the rlinical appearance and circulatory defect of shock.

\section{SUMMARY}

1. Plasma volume, serum protein concentration, hematocrit value, arterial and venous blood pressures, and body weight were determined in ten normal subjects before, and twenty-four hours after, the injection of 2 c.c. of mercupurin.

2. There was a fall in plasma volume in every case, averaging $544 \pm$ 87.7 c.c., or $15.7 \pm 2.4$ per cent of the control determination; an average rise in serum proteins of $0.74 \pm 0.14 \mathrm{Gm}$., or $11.5 \pm 2.6$ per cent : and an average rise in hematocrit of $2.9 \pm 0.6$, or $6.9 \pm 1.8$ per cent.

3. A diuresis was experienced in every case; the mean was $1.73 \div 0.3$ $\mathrm{kg}$., or $2.6 \pm 0.5$ per cent of the body weight.

4. Associated with the diuresis and decrease in plasma volume, there was a fall in venous pressure and pulse pressure.

5. In some instances, the subjects exhibited weakness, apathy, dizziness, and faintness, suggesting a diminution in cardiac output.

\section{RFFERENCES}

1. Gamble, J. L., and MeTver, M. A.: Body Fluid Changes Due to Continued Loss of the Extemal Secretion of the Pancreas, J. Exper. Mer. 48: 859, 1928.

2. Gamble, J. L.: Extracellular Fluid: Extracellular Fluid and Its Vicissitudes, Wm. Sydney Thayer and Susan Read Thayer Lecture, Bull. Johns Hopkins Hosp. 61: 151, 1937 .

3. Mellors, R. C., Muntweyler, E., Mautz, F. R., and Abbott, W. E.: Changes of the Plasma Volume and "Available (Thiocyanate) Fluid" in Experimental Dehydration, J. Biol. Chem. 144: 785, 1942.

4. Gresersen, M. I., and Stewart, J. D.: Simultaneous Determination of Plasma Volume With T 1824, and "Available Fluid" Volume With Sodium Thiocyanate, Am. J. Physiol. 125: 142, 1939.

5. Jacobson, S. D., and Lyons, R. H.: Changes in Blood Folume Produced by Diabetic Acidosis, J. Lab. \& Clin. Med. 27: 1169, 1942.

6. Lyons, R. H., Jacobson, S. D., and Avery, N. L.: The Effect on the Plasma Tolume of Dehydration Produced by a Low-Salt Diet and Ammonium Chloride, AM. HEATT J. 27: 353, 1944.

7. Blumgart, H. L., Gilligan, D. R., Levy, R. C., and Brown, M. G.: The Effect of Diuretics on Water and Salt Metabolism, Tr. A. Am. Physicians 47: 304, 1932.

९. Blumgart, H. L., et al.: Action of Diuretic Drugs, I: Artion of Diuretics in Normal Persons, Arch. Int. Med. 54: 40, 1934.

1. Gibson, J. G., Jr., and Evelyn, K. A.: Clinical Studies of Blood Volume; Adantation of Methorl to a Photoelectric Microcolorimeter, J. Clin. In. restigation 17 : 153,1938 . 
10. Wintrobe, M. M.: The Size and Hemoglobin Content of the Erythrocyte, J. Lab. \& Clin. Med. 17: 899, 1932.

11. Barbour, H. G., and Hamilton, W. F.: Falling Drop Method for Determining Specific Gravity, J. Biol. Chem. 69: 62.5, 1926.

12. Lyons, R. H., Kennedy, .T. A., and Burwell, C. S.: The Measurement of Venous Pressure by the Direct Method, AM. Hrari J. 16: 675, 1938.

13. A. Saxl, P., and Heilig, R.: a. Ueber die diuretische Wirkung von Novasurol und anderen Quicksilberinjectionen, Wien. klin. Wehnsehr. 33: 943, 1920. b. Über die Novasuroldiurese, Ztschr. f. d. ges. exper. Med. 38: 94, 1923.

B. Crawford, J. H., and MeIntosh, J. F.: Observations on the Use of Novasurol in Edema Due to Heart Failure, a. Clin. Tnvestigation 1: 333, 1025.

C. Bohn, H.: a. Experimentelle Studien über die diuretische Wirkung des Novasurols, Ztschr. f. d. ges, exper. Med. 31: 303, 1923. b. Fortgesetzte Studien über Novasurol, seine Wirkung bei verschiedenen Lebensaltern und bei Diabetikern, sowie sein etwaiger. Einfluss auf Ionenverscheibungen in Organismus, Deutsches Arch. f. klin. Med. 143: 225, 1923.

D. Claussen, F.: Über die Diurese der Herzkranken, Ergebn. d, inn. Med. u. Kinderh. 43: 764, 1932 .

E. Meyer, P.: Untersuchungen über den kolloidosmotischen Druck des Blutes II Die Salyrgandiurese, Ztschr. f. Klin. Med. 116: 17t, 1931.

F. Kylin, E.: Studien über den Kolloidosmotischen (onkotischen) Druck XVIII Über die Einwirkung verschiedener Diuretika auf den kolloidosmotischen Druck, Arch. f. exper. Path. u. Pharmakol. 164: 33, 1932.

G. Serby, A. M.: The Pharmacology and Therapeutics of Novasurol, Arch. Int. Med. 38: 374, 1926.

14. A. Nonnenbruch, W.: Uher die Wirkung des Novasurols auf Blut und Diurese, München. med. Wehnschr. 68: 1282, 1921.

B. Oelkers, H. A.: Untersuchungen über den Kolloidosmotischen Druck des Serums, Ztschr. f. klin. Med. 115: 854, 1931.

C. Schmitz, H. L.: Studies on the Action of Diureties I: The Effect of Euphyllin and Salyrgan Upon the Glomerular Filtration and Tubular Reabsorption, J. Clin. Investigation 11: $1075,1932$.

Studies on the Action of Diuretics II: 'The Effect of Salyrgan on the Water Content of the Plasma as Measured by the Refractive Index, J. Clin. Investigation 12: 741,1933 .

D. Bryan, A. H., Evans, W. A., Fulton, M. N., and Stead, F. A., Tr.: Diuresis Following the Administration of Salyrgan, Arch. Int. Med. 55: 735, 1935.

15. Feher, S.: Salyrgandiurese und zirkulierende Blutmenge, Wien. klin. Wehnschr. 42: $964,1929$.

16. A. Brown, G. E., and Rowntree, L. G.: The Volume and Composition of the Blood and Changes Incident to Diuresis in Cases of Edema, Arch. Int. Med. 35: 129, 1925.

B. Swigert, V. W., and Fitz, R.: The Effect of Mersalyl (Salyrgan) on the Plasma Volume, J. A. M. A. 115: 1786, 1940.

17. A. Goldhammer, S., Leiner, G., and Scherf, D.: Uber die zerkulierende Blutmenge vor und nach der Quecksilberdiurese, Klin. Wchnschr. 14: 1109, 1935.

B. Evans, W. A., Jr., and Gibson, J. G.: The Blood Volume in Diuresis, Am. J. Physiol. 118: $251,1937$.

C. Calvin, D. B., Decherd, G., and Herrmann, G.: Response of Plasma Volume to Diuretics, Proc. Soc. Exper. Biol. \& Med. 44: 529, 1940.

D. Hermann, G., Decherd, G. M., and Calvin, I). B.: The Application of Blood Volume Studies to the Theory of the Mechanism of Diuresis, Tr. A. Am. Physicians 56: 298, 1941.

18. Goverts, P.: Origine renale ou tissulaire de la diurèse par und composé Mercurial organique, Compt. rend. Soc. de biol, 99: 647, 1928.

19. Christian, H. A., and Bartram, E. A.: Experimental Observations on the Action of Diuretics, Tr. A. Am. Physicians 47: 292, 1932.

20. Herrmann, G., et al.:

A. Some Studies in the Mechanism of Diuresis in Patients With Congestive Heart Failure, Tr. A. Am. Physicians 47: 279, 1932.

B. Further Studies on the Mechanism of Diuresis in Patients With Congestive Heart Failure, Tr. A. Am. Physicians 48: 364, 1933.

C. Herrmann, G., and Decherd, C.: Further Studies on the Mechanism of Diuresis With Especial Reference to the Action of Some Newer Diureties, J. Lab. \& Clin. Med. 22: 767, 1937.

21. Calvin, D. B., Decherd, G., and Herrmann, G.: Plasma Protein Shifts During Diuresis, Proc. Soc. Exper. Biol. \& Med. 44: 529, 1940. 
22. Lyons, R. H., Jacolson, S. D., and Neerken, A. J.: To, be published.

23. A. Gamble, J. L., Blackfan, K. D., anıl Hamilton, B.: A study of Diuretie Action of Acid Producing Salts, J. Clin. Investigation 1: 359, 19:5.

B. Fylling, A.: On the Mechanism of the Ammonium Chloride Acidosis, Acte med. Scandinax. 71: 221, 1929.

1: Loeh, R. F., et al.: On the Mechanim of Nephrotiv Edema, I. Clin. In vestigation 11: 621,1932 .

1). Wiley, F. H., Wiley, L. L., and Waller, D. S.: 'lhe Eifeet of the Ingextion of Sodium Potassium and Ammonium (hlorides and Sodium Bicarbonates on the Metabolism of Inorganic Salts and Water, J. Biol. ('hem. 101: $73,1933$.

24. Poll, D., and Stern, J. E.: Daigers of Dehydration Treatment in Heant Disease, M. Clin. North America 21: 1873, $193 \%$.

25. A. Stead, E. A., Jr., and Ehert, R. V.: Relationship of the Plasua Volume and the Cell Plasma Ratio to the Total Red cell Volume, An. J. Phrsiol. 132: 411,1941 .

B. Ebert, R. V., and Stead, E. A., Jr.: I)monstration That the Cell Plasma. Ralio of Blood Contained in Minute Vessels Is Lower That in That of lewous Blood, J. Clin. Investigation 20: $317,19 \pm 1$.

(. Stewart, J. D., and Rourke, G. ML: Changes in the Blood and Interstitial Fluid Resulting From Surgical Operation and Fther Anesthesia, I. Clin. Investigation 17: 413,1938 .

D. Mellors, R. C., Muntweyler, E., Mautz, F. R., and Abhott, Wr. E.::

E. Lyons, R. H., Jacobson, S. D., and Avery, N. I..:

F. Calvin, D. B., Decherd, G., and Hermarin, G.:21

26. Ryder, H. W., Molle, W. E., and Ferris, E. B., Jr.: The Significance of the Peripheral Venous Pressure, Proc. Centrai Soc. Clin. Researeh 14: $t 4$, 1941.

37. Richards, D. W., Jr., Cournand, A., Darling, R. C., and Gillespie, W. H.: J'exsure in the Right Auricle of Man in Normal Subjerts, and in Patients With Congestive Heart Failure, Tr. A. Am. Physicians 56: 218, 1041.

2x. Holt, J. P.: The Collapse Factor in the Nessurement of Fenous Prosme. An. J. Physiol. 134: 292, 1941.

29. Warren, J. V., and Stead, E. A., Jr.: The Effect of the Accumulation of Blood in the Extremities on the Tenous Pressure of Normal sulj.jets. Am. I. M. Sc. 205: 501, 1943. 